\title{
6. Diversity reportage in Aotearoa: Demographics and the rise of the ethnic media
}

\section{ABSTRACT}

For more than two decades, diversity has been a growing mantra for the New Zealand news media. Initially, the concept of biculturalism-partnership with the indigenous tangata whenua-was pre-eminent in the debate, but as the nation's Pasifika and ethnic media have flourished and matured and demographics have rapidly changed, multiculturalism has become increasingly important and challenging. The regional media relationship in the context of contested notions such as the 'arc of instability' and the impact of coups and crises on journalists has become critical. Projected demographics by Statistics New Zealand indicate that the country's Asian population will almost double by 2026. The Pasifika and Māori populations are also expected to grow by 59 and 29 per cent respectively. Māori, Pasifika and ethnic media in Aotearoa/New Zealand are also steadily expanding with implications for the media industry and journalism educators. This article examines the regional trends and how initiatives such as the Pacific Media Centre and new journalism courses with an emphasis on diversity are addressing the challenges.

Keywords: biculturalism, cross-cultural reporting, diversity, multiculturalism

\section{DAVID ROBIE}

Pacific Media Centre, AUT University

\section{Introduction}

IMPLISTIC notions and prejudices about the Asia-Pacific region pose
challenges for journalists in Oceania attempting to report with depth,
context and analytical skill. Pressures and dilemmas for the news
media continue to gain momentum in the South Pacific, often from a 
cultural as well as socio-political dimension. For more than two decades, diversity has been a growing mantra for the Aotearoa/New Zealand media. Initially, the concept of biculturalism-partnership with the indigenous tangata whenua-was pre-eminent in the diversity debate, but as the nation's demographics have rapidly changed and Pasifika and ethnic media have flourished and matured, multiculturalism has become increasingly challenging and important. The emergence of biculturalism has crystalised into one of the most important social and political developments in New Zealand in the past 50 years (Archie, p. 3; 2007, p. 3; Belich, 1996). The notion of a partnership between the indigenous Māori peoples and the Pākehā (descendants of European colonists, most Anglo-Saxon, and more recent migrants) was enshrined in Te Tiriti-the 1840 Treaty of Waitangi, regarded as the nation's 'Magna Carta'. This founding document of nationhood has underpinned a revival of civil rights and Māori culture since the 1960s. Te reo Māori is one of New Zealand's three official languages (along with English and Sign language).

However, since the turn of this century, the principles of bicultural development have become increasingly contested by notions of multiculturalism. New Zealand is a country with one of the highest global per capita migration rates (Singham, 2006, p. 33). The 2001 Census indicated that 10 percent of the people comprised ethnic migrant communities other than Māori and Pasifika. Projected demographics by Statistics New Zealand (2008) indicate that the country's Asian population could almost double by 2026. The Pacific and Māori populations will also experience increases of 59 and 29 percent respectively. A strategic approach to multicultural diversity is increasingly apparent and essential.

Recognition of cultural diversity and celebration of migrant communities present mounting challenges for media as a counterpoint to globalisation (Deuze, 2004; Morgan, 2006). The 'mainstream’ New Zealand media has been slow to adapt to the changes heralded by biculturalism, and it is now also confronted with having to reflect and respond to a rapidly changing and increasingly complex multicultural society. Major cutbacks in New Zealand news organisations, particularly the two major newspaper chains, APN News and Media and Fairfax Media_-both Australian-owned-in recent years has meant an increasing reliance on reporting the region through a globalised prism, especially as seen from Canberra, even though this often does not 
match a New Zealand perspective of the Asia-Pacific region (James, 2006; Robie, 2004, 2007). The regional media relationship in the context of contested notions such as the 'arc of instability' and the impact of coups and crises in countries such as Fiji, Papua New Guinea and the Solomon Islands on journalists has become critical (see Field, 2005; Robie, 2004, 2008; Tully, 2005). While the media in some countries is refreshingly outspoken and courageous, in others there is a trend towards self-censorship. There is a growing need to challenge images of the region beyond 'coups, conflicts and contraband' (Helu Thaman, 2001). This article examines the regional trends and their impact on the future for mainstream media and journalism education in a globalised context and how initiatives such as the Pacific Media Centre at AUT University are addressing the challenges of demographic change.

\section{Media and the Asia-Pacific region}

Four companies, all foreign owned, dominate the New Zealand news media industry (Figure 1), including a 'near duopoly in two of the three main media - print and radio. (Rosenberg, 2008, p. 176). In television, there is a monopoly in the pay arena (News Corporation-owned Sky TV), and only three significant competitors in free-to-air television, including the state-owned Television New Zealand's two channels. Australian-owned Fairfax Media controls almost half of the country's newspapers (more than 48 percent), including The Dominion Post in the capital of Wellington, while the rival APN News and Media (ANM) group - also Australian-ownedcontrols the largest circulation daily, New Zealand Herald and almost 43 percent of the daily newspaper circulation. The main media union, Engineering, Printing and Manufacturing Union (EPMU), has described the New Zealand media as the 'most concentrated and foreign-dominated' in the world (Rankine et al., 2007). During 2007, APN 'outsourced' the bulk of the subediting of its titles to the Australian-owned Pagemasters company. In mid-2008, the national news agency, NZ Press Association, downsized and retrenched seven staff while Fairfax Media announced plans to shed 40 editorial jobs and centralise subediting and some specialist newswriting into selected centralised nodes for its newspaper chain in a controversial new era of cloned 'hubeditors' (Mediawatch, 6 July 2008). The media industry has frequently declared that it wants to adopt newsroom and staffing strategies geared towards greater diversity but the reality has shown slowness to 
change (Tucker, 2007). Pressures resulting from media convergence, staff layoffs and cost-cutting also impact on efforts to diversify in the newsroom. The largest daily newspaper has less than five 'diversity' journalists in an editorial staff of 140-barely 4.6 percent of the newsroom team. This situation has contributed to an apparent decline in the quantity and quality of Asia-Pacific coverage in New Zealand media.

Journalists committed to covering the Pacific region frequently find it frustrating while working with news media that do not employ sufficient resources, or misread or interpret events simplistically and without sufficient depth. According to Louw, misreadings often occur because journalists work in 'closed shop' reporting environments, carry their cultural biases with them into an assignment, and assume their own news and social values to be 'universally valid truths and uncontestable, partly because the new world order is a de facto Anglo hegemony' (Louw, 2004, 154). Vanuatu-based photojournalist Ben Bohane, for example, is in the vanguard of those who have brought an independent and critical perspective to the region's coverage in the media. A curator's commentary for a Sydney exhibition of his work in 2006 concluded: "The media maxim "If it bleeds, it leads" may account for [an Australian] tendency to focus on eruptions in a perceived status quo rather than monitoring the sequence of events that precede or influence them' (Dean, 2006, p. 157).

Such tendencies equally apply to the New Zealand media. However, at a policy level New Zealand has a self-perception of being from the Pacific rather than in the Pacific as is the case with Australia. This is partially influenced by the relatively large population of Pacific Islanders living in New Zealand (almost 266,000 in a total population of more than 4 million at the 2006 Census). Former Agence France-Presse reporter Michael Field, with a wide regional brief and who now works for Fairfax Media in New Zealand, has complained frequently about the lack of quality of New Zealand coverage of the region: 'There's a lack of respect in every aspect of how New Zealand covers its own Pacific Island people and how we cover the Pacific' (Mediawatch, 2001). According to Jim Tully, New Zealand coverage of Pacific affairs has been eroded by relatively few resources devoted to foreign news and many reporters failing to go beyond a 'goodies and baddies' view of events. An example of this was the one dimensional reporting of the Fiji post-coup crisis in April 2008 where there was little attempt at fair and balanced reporting. According to Tully: 
This reduction in the use of foreign correspondents, with their greater depth of understanding, has seen an increased reliance on what has been variously called 'hit and run' or 'parachute' journalism. This is when people who have a relatively small knowledge of a particular nation or political issue are dispatched for a short-period to file ongoing daily coverage and then some kind of analytical wrap-up at the end of the week or fortnight. The coverage is usually of some sort of conflictpolitical or military—or a natural disaster. (Tully, 2005, p. 296)

While the development of Māori and iwi media—notably Māori Television since its establishment in 2004 - and their integration with the indigenous community have been reported on and analysed by several researchers and writers (Archie, 2007; Stuart, 1996, 2002; Taira, 2006), there has been little analysis of the Pacific media and community. Taira's perspectives on Māori media also apply to Pasifika media:

Self-determination for many Māori requires Māori control. In practice, this means not imposing a media model or a niche slot on Māori, but providing instead the resources necessary to determine their own media models and forms of media ... only when this happens will Māori be effectively participating in the mainstream media. (Taira, 2006, p. 277)

\section{Demographic projections indicate growing diversity}

New Zealand used to be an overwhelmingly 'European' country. In 1956, almost 93 percent of the population identified as European, 6.3 percent Māori and 0.4 percent Pacific Islander. Fifty years later, the demographic breakdown had become 67.6 percent European/Pākehā, 14.6 percent Māori and 6.9 percent Pasifika with 9.2 percent Asian and 0.9 percent from the Middle East.

Religious affiliation has also changed significantly in recent years. While New Zealand has traditionally been predominantly a Christian country since colonisation, this defining characteristic has eroded quite sharply since the turn of the century. In the 2006 Census, barely more than 2 million people, or 55.6 percent of those answering a religious affiliation question, identified with a Christian religion (including Māori Christian, such as the Ratana faith). In the previous 2001 Census, 60.6 percent of surveyed people affiliated with a Christian religion. In contrast, between 2001 and 2006 there was an increase 
of people affiliated with non-Christian religions. The number of Sikhs, for example, grew from 5196 to 9507 (an increase of 83 percent) while people affiliated with Hinduism (a rise from 39,798 to 64,392) or Islam (up from 23,631 to 36,072) also grew by more than 50 percent.

The proportion of people who identified as Pacific Islanders in New Zealand grew by 14.7 percent to 265,974 in the 2006 Census. Overall Pacific people comprise almost 7 percent of the total NZ population of 4,027,947 (Statistics NZ, 2006). Pacific communities have grown rapidly in recent years (Graphs 1 \& 2) with at least three countries and territories - Cook Islands, Niue and Tokelau - having more than two-thirds of their population living in New Zealand. The number of Pacific Islanders living in New Zealand would make it the fourth largest 'Pacific' country by population - after Papua New Guinea, Fiji and the Solomon Islands, and the city of Auckland is often described as the 'Polynesian capital of the world'. Both the Māori and Pacific media have expanded and transformed along with the demographic changes and played a critical role in self-determination. Ethnic media is in its infancy but also rapidly evolving.

\section{Graph 1: People from Pacific countries living in Aotearoa/NZ}

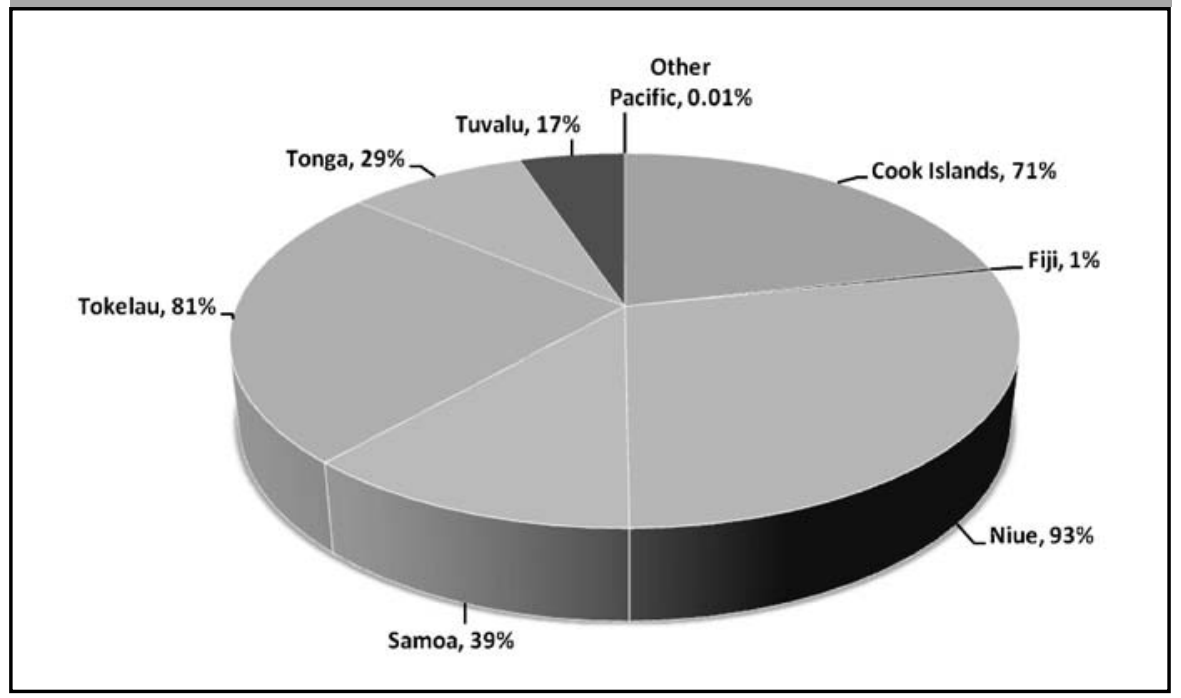

Source: Statistics NZ, 2001 Census. The trend continued at the 2006 Census. The pie chart represents the proportions of the total populations from each country living in New Zealand. 


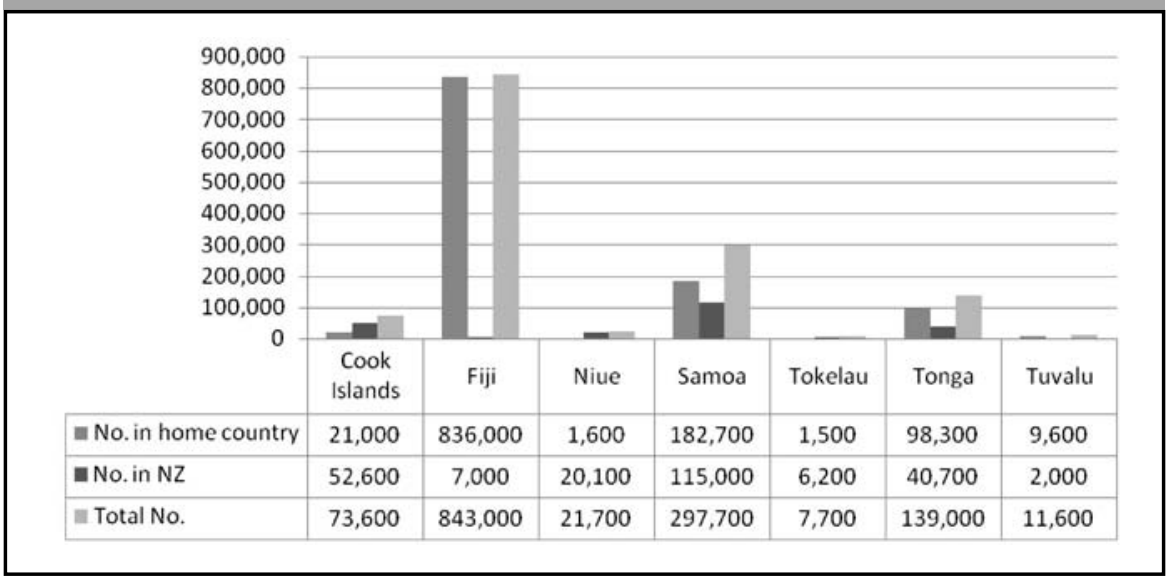

Source: Adapted from McCarthy, L. (2005: 44); The original statistics table includes the category "other Pacific", ie. American Samoa, Federated States of Micronesia, French Polynesia, Guam, Kiribati, Marshall Islands, Nauru, New Caledonia, Northern Mariana Islands, Palau, Papua New Guinea, Solomon Islands, Vanuatu and Wallis and Futuna. This figure included 7,472,200 (mostly Papua New Guinea) Pacific people living in their home countries and 7000 living in New Zealand.

\section{The Māori media renaissance}

A characteristic of the print record in New Zealand has been a strong presence of Māori voices, expressed in both English and te reo Māori. According to Taira (2006), Māori has been 'an essential printed and spoken element of New Zealand culture' from the earliest missionary presses until the contemporary Huia Publishers, which celebrates indigenous writing. She identifies three critical periods in the development of indigenous print media — colonising journalism, kaupapa Māori journalism and niche journalism.

A media revival accompanied a Māori cultural renaissance of the 1980s with the establishment of several newspapers and magazines, followed by the birth of iwi, or tribal-based, and urban Māori community radio stations; the first Māori cyber-navigators such as Ross Himona and the indigenous domain maori.nz in the mid-1990s, and an ill-fated Aotearoa Māori Television Network pilot project.

Finally, indigenous media in New Zealand was transformed with the establishment of Māori Television in March 2004, which seeks to be a worldclass, indigenous broadcaster with a mission 'to provide an independent, secure and successful Māori television channel making and broadcasting 
programmes that make a significant contribution to the revitalisation of tikanga and te reo Māori' (cited by Taira, 2006: 257). It now broadcasts on free-to-air UHF terrestrial, Sky TV pay-view and Freeview digital satellite platforms. Māori Television came of age in March 2008 when it hosted the inaugural World Indigenous Television Broadcasting Conference (WITBC) attended by broadcasters from Australia (NITV), Canada (APTN), Cook Islands, Fiji (Fiji TV), Ireland (TG4), Scotland (BBC Gaelic), South Africa (SABC), Taiwan (TITV and PTS) and Wales (S4C). Tāhūhū Rangapū, or CEO, Jim Mather explained the station's two-channel strategy (the new digital channel is 100 percent te reo Māori) as a balancing act: 'How do we fulfil our statutory obligations, while balancing commercial and cultural imperatives and, in the process, make a significant contribution to the revitalisation of the Māori language and culture?' (Mather, 2008).

Te reo Māori language proficiency is 27 percent with a core audience of 166,000 proficient Maori speakers - 4 percent of the total population (ibid.). Two-thirds of the monthly average audience of 1.3 million individual viewers are non-Māori. Commissioned programme funding is supported by Te Mangai Paho, a government-funded agency set up to support Māori broadcasting.

\section{Figure 1: Maori Television's strategy for success, 2006}

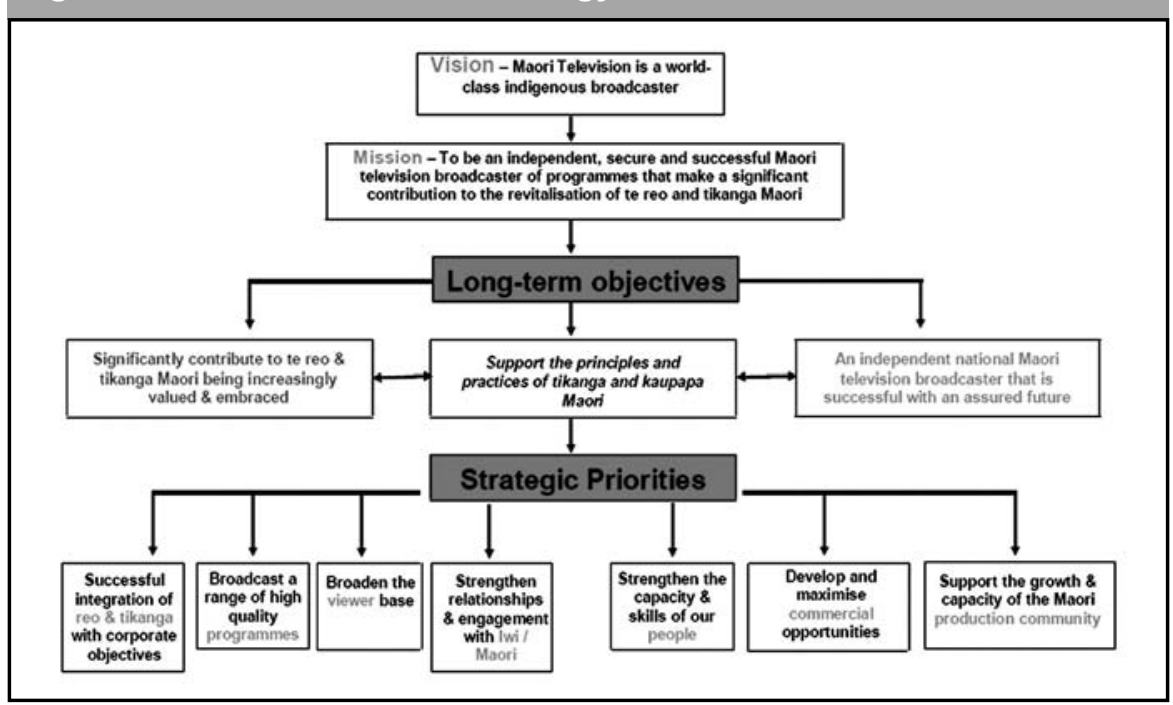

Source: Mather (2008). Making a 'significant contribution to revitalisation of Māori language and culture'. 
The network caters for this core audience with a range of niche programmes, a council of nine elders (kaunihera kaumatua) who provide cultural advice and support, a news and current affairs department of 32 staff and an in-house production team of 78 staff (Figure 1).

In February and March 2007, a report by the Kupu Taea media project (Rankine et al, 2007) related to the Treaty of Waitangi analysed a representative group of 740 newspaper articles and 118 television news items about Māori issues over a two-week period in February-March. Using discourse and content analysis methodology, the research team found average low levels of the use of te reo Māori, with 'roughly half containing no Māori words for which there are English alternatives. Te Kaea [Māori Television news] and Te Karere [state broadcaster Television NZ's Māori news bulletin] used iwi affiliations with the name of Māori speakers, but these were very rarely provided by mass television news or newspapers'. The researchers also found that many newspaper stories were written from a Pākehā perspective and represented Māori as a source of problems or conflict. The team criticised the widespread use of a 'Māori privilege' frame or theme, especially as this had been rejected as unfounded by the UN Special Rapporteur on Indigenous Peoples, Rodolfo Stavenhagen, following a visit to New Zealand in 2005:

This enduring and self-serving Pākehā theme enabled Māori to be viewed as having privileges unfairly denied to Pākehā while also being depicted as poor, sick and a 'drain on the taxpayer'. (Rankine et al., 2007, p. 9)

According to Stuart (1995, 2002), applying the Four Worlds news values model for development media (see Robie, 1995, 2005a) as a frame, Māori media tend to move across all four categories instead of being restricted to First World 'objectivity' — within the Second World category, lies a political agenda concerned with tino rangatiratanga (sovereignty); in the Third World, 'culture-building' substitutes for 'nation-building'; and the Fourth World incorporates Māori media’s concern with cultural survival and language revitalisation. In a later article tracing cultural identity since the 19th century, Stuart (2003) argued that Māori media was contributing to the creation of a 'Māori nation' within New Zealand. 


\section{The Pasifika news media}

Most Pacific Island communities in New Zealand are now well served by radio, newspapers, online media and, partially, television. Almost all of these media services are owned or are run by Pacific Island businesses or organisations based either in New Zealand or in the Pacific (Utanga, 2007, p. 20). Notable success stories in recent years include the long-established Tagata Pasifika weekly current affairs magazine on Television New Zealand (and also rebroadcast on Māori Television) and the Auckland-based radio station NiuFM, established and managed under the umbrella of the National Pacific Radio Trust (NPRT) and Auckland-based Spasifik magazine, which now has a strong pan-Pacific readership. NiuFM and pioneering Auckland Pacific community radio station 531pi merged in 2006 and have established Pacific Radio News, which provided, for example, strong and independent coverage of Fiji's fourth coup and the 2006 Tongan riots and reconciliation. However, the community trust operator of NiuFM and 531pi, Pacific Media Network, during 2008 became embroiled in a controversy over the independence of its news service in election year. The future of its more than $\$ 12.3$ million government subsidy has been questioned. It was feared by some Pacific broadcasters that if the opposition National Party gained power in the general election in October 2008, funding could cease or be dramatically curtailed and the future of the station would be at risk (Brown, 2008; Dreaver, 2008).

Pacific communities are not well served by the mainstream media. However, some mainstream media organisations have tried in recent years to strengthen their regional coverage. Several leading Pacific journalists cover island affairs for mainstream broadcast media. Television New Zealand, for example, formed a Pacific reporting unit after the George Speight coup of May 2000 (Gounder, 2007; Mason, 2007). Barbara Dreaver, of part Kiribati ethnicity, was one of the establishment team of two-members. But this team was later cut back to one person and Dreaver is now TVNZ's only fulltime Pacific reporter. Cook Islander Richard Pamatatau reports for Radio New Zealand National while a young Samoan graduate, Leilani Momoisea, of AUT University, is gaining prominence as a general news reporter for RNZ.

Radio NZ International's team covering the region includes specialist Pacific Island reporters. RNZI won the 2007 global radio station of the year award ahead run by the Association of International Broadcasting (AIB) of the $\mathrm{BBC}$, for example, because of its Pacific coverage ('Radio NZ International 
wins global awards,' 2007). It also won a special Media Peace Prize for its Pacific coverage. However, no New Zealand daily newspaper has a specialised Pacific issues reporter on the staff who is actually a Pacific Islander. These news organisations employ non-Pacific reporters to cover the region and their lack of cultural knowledge, history and background is often embarrassingly obvious.

Gary Wilson pioneered Maori and Pacific Islands journalism training with the then NZ Journalists Training Board (now Journalists Training Organisation-JTO) in the 1980s and then helped run the Mana news service and publish the bimonthly magazine Mana from 1990 to 2004. He has been an established critic of mainstream media's diversity failings. In a commissioned paper for the JTO, he wrote:

I see the initial problem in the media as a failing to reflect Māori lives and interests as fairly and generously as they should be. The failing to reflect the news and views of Samoan, Tongan and Cook Island New Zealanders and other Polynesian Kiwis from the Pacific is a parallel problem. (Wilson, 2006, p. 3)

The Melanesian and Micronesian contributions to New Zealand life are even more invisible and this reflects the mainstream media's neglect of both these sub-regions in the Pacific. Papua New Guinea, the most populous nation and largest economy among Pacific Islands Forum (PIF) member countries is rarely covered by New Zealand media and few journalists have a sound working knowledge of the country. Vanuatu and the French-speaking territories, French Polynesia, New Caledonia/Kanaky and Wallis and Futuna, are also seriously under-reported by New Zealand media, with RNZI being the only exception.

According to Wilson, Pacific Island leaders in NZ have been slow to recognise the part media plays in influencing Pasifika developments (2006, p. 3). They have also been reluctant to push their agenda, remaining content to defer to the tangata whenua. In this campaign for a better deal in the media, Pacific Islanders have been 'playing a subdued, secondary role'.

John Utanga, co-founder and former chairman of the Pacific Islands Media Association (PIMA), has a rather more optimistic view (2007). He notes that coverage has often been restricted to 'headline 
grabbing' events issues - such as overstayers, crime, coups and conflict. Important stories about immigration issues, achievements and human endeavour have often been left to Pacific Islands media to provide coverage. But changes have indeed been happening in the last decade: [T] $]$ ere appears to have been a slight shift in the way the mainstream media covers Pacific issues and perhaps this has come about because of a wider awakening or understanding about New Zealand's neighbours and the country's place in the Pacific. Certainly, events, in the region covers the past 20 years, from military takeovers to natural disastersand open warfare in some cases - mean the Pacific is difficult to ignore. (Utanga, 2007, p. 25)

\section{The Asian and ethnic media}

The Asian and other ethnic minority communities in New Zealand also feel short-changed by the mainstream media and regard themselves as marginalised or ignored by reporters and editors. Even experienced journalists and editors from abroad feel marginalised by the New Zealand media, often overlooked for jobs because they lack 'New Zealand experience' (Asian people excluded from media, says TV producer, 2008). Lincoln Tan, a former journalist from Singapore Press Holdings, responded to the challenge by launching an English-language newspaper with an Asianfocus - iBall - in 2003. He also became a regular columnist for the New Zealand Herald and now reports regular news for the Herald. Ironically, he was rather critical of that newspaper, which has the country's largest circulation (200,309), when he first arrived in New Zealand in 1997. He regarded it as typical of the lack of mainstream media interest in the Asian communities:

I found the stories in the New Zealand Herald to be of little relevance to me. They seem[ed] to be reported for an audience quite different from me, and as an Asian, I have become 'them'. Within a space of three months, I stopped reading newspapers on a daily basis, and had instead turned to the internet for my source of news. (Tan, 2006, p. 1)

Tan believes it is a mistake for mainstream newspapers to attempt to publish publications in Chinese - 'or any ethnic script for that matter'-as the Herald did during the mid-1990s. He argues that mainstream media should be doing more to win Asian readers for their main papers. He considers 
far more information is needed about the nature of Asian journalism and journalists in New Zealand and encourages more wide-ranging research. In a 2006 commissioned paper for JTO on 'Asian involvement in mainstream media', Tan attempted to sketch an overview of Asian media, particularly Chinese, while stressing that an Indian readership was totally different, provided a raft of recommendations including a call for major reforms by mainstream media to embrace diverse communities:

With the changing face of New Zealand, as we head down the path of multiculturalism, mainstream media must be prepared to evolve and take the bold step to admit-yes, here is a need or change. (Tan, 2006, p. 2)

Currently 71 ethnic minority newspapers or magazines are being published in New Zealand along with seven ethnic radio stations (excluding the access radio networks), three television programmes and two major web-based news services (Wong, 2006). The publications surveyed by the Ethnic Media Bureau (Table 1) include 15 Chinese newspapers in Auckland-ranging from iBall (renamed AsianToday) to The Epoch Times (published by the members of the Falun Gong movement), two Chinese papers in Hamilton and three Chinese papers in Wellington. Twelve Korean newspapers are published in Auckland alone. Nine Indian newspapers are published, three Filipino, five Samoan and four Tongan. A new Indian fortnightly, Indian Weekender, headed by an Indo-Fijian editorial team, was launched in March 2009, pledging to challenge existing papers that had been 'stuck in the 1970s' with brighter and more relevant content and layout (Segedin, 2009).

Low points in mainstream media coverage of ethnic issues have included the so-called 'Asian Angst' affair concerning a xenophobic article about Asian immigration and crime published by one of the country's leading current affairs glossy magazines, North \& South, owned by ACP media. Titled 'Asian Angst: Is it time to send some back', the article written by former member of Parliament and journalist Deborah Coddington, was alleged to have distorted use of statistics and made liberal use of emotive terms such as 'the gathering crime tide' and the 'Asian menace'. The controversial article provoked a series of complaints, including from the Asia New Zealand Foundation, journalists and a journalism educator to the 


\section{Table 1: Māori, Pasifilka and ethnic media in Aotearoa/NZ}

\begin{tabular}{|c|c|c|c|}
\hline \multicolumn{2}{|c|}{ Māori (tangata whenua) press } & \multicolumn{2}{|l|}{ Korean press } \\
\hline Mana magazine & bimonthly & \multicolumn{2}{|l|}{ Auckland } \\
\hline Tu Mai & bimonthly & \multicolumn{2}{|l|}{ Christian Life } \\
\hline Pu Kaea & weekly & \multicolumn{2}{|l|}{ Gooday New Zealand } \\
\hline \multicolumn{2}{|l|}{ Pacific media } & Korea Times & weekly \\
\hline Spasifik magazine & bimonthly & Korea Town & weekly \\
\hline \multicolumn{2}{|l|}{ NiuFM } & Newstoon & weekly \\
\hline Radio 531pi & & \multicolumn{2}{|c|}{ NZ Information for International Students } \\
\hline \multicolumn{2}{|l|}{ Fiji } & \multicolumn{2}{|c|}{ NZ Sunday Times weekly } \\
\hline Fiji Observer & Infrequent & NZ Times & weekly \\
\hline \multicolumn{2}{|l|}{ Samoan } & Property Journal & weekly \\
\hline \multicolumn{2}{|l|}{ Samoa International } & Sunday Seoul & weekly \\
\hline Samoa Observer & daily & \multicolumn{2}{|l|}{ The New Korea Herald } \\
\hline Le Samoa Post & weekly & \multicolumn{2}{|l|}{ Christchurch } \\
\hline * Samoana & weekly & \multicolumn{2}{|l|}{ Korea Review } \\
\hline Samoa Times & weekly & \multicolumn{2}{|l|}{ The Christchurch Times } \\
\hline \multicolumn{2}{|l|}{ Tongan press } & \multicolumn{2}{|l|}{ Japanese press } \\
\hline Taimi ‘o Tonga & biweekly & E Cube & weekly \\
\hline Tongan Independent & weekly & \multicolumn{2}{|l|}{ Gekkan NZ } \\
\hline \multicolumn{2}{|c|}{ Free Wesleyan Church of Tonga } & & \\
\hline \multicolumn{2}{|c|}{ Chinese press } & Quarter & \\
\hline Auckland & & Indian press & \\
\hline Asian Voice & weekly & Auckland Times & \\
\hline Auto Market & weekly & Awaz Punjabi News & \\
\hline Chinese Express & weekly & Hum & \\
\hline Chinese Herald & weekly & India Newslink & weekly \\
\hline Chinese Times & weekly & Indian Tribune & weekly \\
\hline i Ball (now Asian Today) & weekly & Indo Times & weekly \\
\hline Mandarin Times & weekly & Kuk Punjabi Samachar & \\
\hline New Times & weekly & Merge Magazine & \\
\hline NZ Chinese Bizlink & weekly & Kiwi India Directory & \\
\hline NZ Life Weekly & weekly & Other ethnic media & \\
\hline NZ Mirror & weekly & Al Mujaddid & \\
\hline Oriental Times & weekly & Bangkok News & \\
\hline Property Overview & weekly & Thai NZ News & \\
\hline The Epoch Times & weekly & NZ Jewish Chronicle & weekly \\
\hline WTV Magazine & weekly & Migrant New & \\
\hline Hamilton & & Neuseeland News & \\
\hline Waikato Weekly & weekly & Our Hobour (Russian) & \\
\hline Waikato Chinese Times & weekly & Radio & \\
\hline Wellington & & Chinese Radio 90.6FM & \\
\hline Capital Chinese Times & weekly & Chinese Radio 936 & \\
\hline Home Voice Chinese We & Jews & K88.3/FM96.1 (Korean) & \\
\hline NZ Chinese Times & & Television & \\
\hline Christchurch & & World TV (Chinese, Korean) & \\
\hline The Messenger & weekly & Golden raindrop TV (Chinese) & \\
\hline The Sun & weekly & Indianz TV & \\
\hline Filipino press & & Web media & \\
\hline Diario Filipino & weekly & Skykiwi (Chinese) & \\
\hline Filipino Herald & weekly & The Global Indian & \\
\hline
\end{tabular}

Source: Adapted from Ethnic Media Bureau, 2006. This list does not include ethnic franchise programmes such as Asia Down Under on Television NZ or on community access style radio or television programmes. * Now closed. 
NZ Press Council, which ruled that the article breached principles governing accuracy and discrimination (Oliver, 2007).

Following the Danish cartoons affair over the depiction of images of the Prophet Mohammed - several of which linked the Prophet and Islam with terrorism - by a group of cartoonists and published in Denmark's JyllandsPosten newspaper on 30 September 2005, a wave of violent protests and unrest happened in several countries. Three leading New Zealand newspapers also published the cartoons. The Dominion Post, Christchurch Press and Nelson Mail ran the cartoons, arguing solidarity with the principles of a free press. The country's largest daily newspaper, New Zealand Herald, refused to run the cartoons, invoking principles of editorial responsibility. TVOne and TV3 news bulletins broadcast images in the context of local reaction, which was highly critical but peaceful. New Zealand Muslim communities, and many other groups, including Christians, took formal complaints to the Human Rights Commission. Although the complaints fell outside the jurisdiction of the Human Rights Act, the Race Relations Commissioner invoked the Commission's wider mandate and met with Muslim community leaders and newspaper editors. Adraft code of conduct was developed, which encouraged greater sensitivity to ethnic, religious and cultural issues by newspapers when making editorial judgments (10 human rights cases that made a difference, 2006).

\section{The genesis of diversity journalism education}

Almost three decades ago, the then Department of Māori and Pacific Island Affairs and the Journalists Training Board linked up to run a series of five-day introductory journalism courses for Māori and Pasifika students (Wilson, 2005). This programme, continued for much of the 1980s, had been a response to a national survey of journalists which then indicated that just under two percent of New Zealand's journalists were Māori or Pacific Islander (Lealand, 1988). This initiative was followed in 1985 with the establishment of a full-time journalism course primarily for Māori students at Waiariki Polytechnic. (After weathering uncertain times over several years, the course has been strengthened and it introduced a major new strategy in 2008 with the introduction of a Diploma in Bicultural Journalism (Waiariki, 2007).) In 1986, the Manukau Polytechnic introduced a similar course for Pasifika students, which attracted journalists from the South Pacific region with Ministry of Foreign Affairs funding. But although this latter course gave 
up to a dozen Pasifika journalists a year a 'vital leg-up into the industry', as Utanga described it (2007, p. 27), the course was closed in 1994 after the ministry grant had been phased out.

Many of the leading Māori and Pasifika journalists working in the media industry today are products from this training and education period (Wilson, 2006), including Barbara Dreaver, Sandra Kailahi, Jodi Ihaka, Nevak Ilolahia, Joe Lose, Mike McRoberts, Tapu Misa, Te Anga Nathan, Gideon Porter, Niva Retimanu, Lois Turei, John Utanga and Lito Vilisoni. Today, there is an increasing call for journalism education and training to help Pasifika journalists 'tell our stories and provide our side of the debate' (Utanga, p. 28) and for ethnic minority journalists to report the news from their own perspective (Tan, 2006, p. 1).

The Diploma in Bicultural Journalism at Waiariki is headed by the former news manager of indigenous-owned Imparja Television Network, Bruce Honeywill, with local indigenous staff Dave Kiel and Lani Kereopa. The pressure for change has also led to the first te reo Māori media course at Manukau Institute of Technology (2007); a revamped Diploma in Multimedia Journalism at Whitireia Community Polytechnic in 2008 aimed at 'ethnic minorities' and a relocation of the journalism school to Wellington (Whitireia journalism diploma goes mid-year, 2007); and a proposal for a new Māori Media and Communication degree major at the University of Waikato with innovative new papers such as 'From Whaikōrero to Bebo: Evolution of Māori Media and Communication' (2009). AUT University also won government approval for a new Graduate Diploma in Pacific Journalism due to start in 2010 as an addition to the country's largest Communication Studies programme.

In 2007, the JTO and Asia New Zealand Foundation sponsored a tour by Arlene Morgan, associate dean of the Columbia School of Journalism and coeditor of The Authentic Voice (2006), to various journalism schools, including AUT Journalism's annual journalism kōrero at Hoani Waititi urban marae in May, highlighted pointers to better diversity reporting. Morgan returned to New Zealand in mid-2008 to support a new national diversity journalism award to promote outstanding reportage in the field.

\section{Demographics and journalism education}

According to the most recent national journalism survey conducted by the industry (Journalists Training Organisation, 2007), four out 


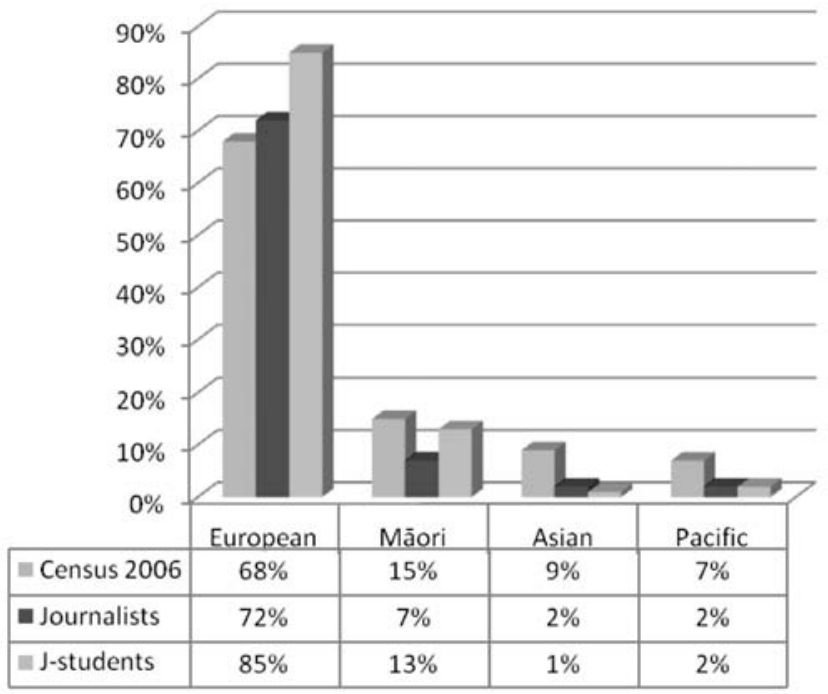

Source: Adapted from Tucker (2007). While the proportions of Asian and Pacific journalism students are far below the Census 2006 figures, the proportion of Māori students appears more promosing. However, the majority of Māori students are at Waiariki. With Waiariki excluded, the proportion drops to 9.3 percent.

of five journalists (83 percent) were European/Pākehā-European,with another 8.5 percent recording themselves as Māori (3 percent) or MāoriPākehā (5.5 percent). The only other groups to register above 1 pecent were Chinese (1.2 percent) and 'Australians' ( 1.2 percent), while 6 percent said their ethnicity was something other than the options listed in the question. This means that Pasifika journalists dropped below the radar at less than 1 percent even though there is a rapidly growing Pacific media and not enough trained Pasifika journalists. An independent national survey (Hollings et al., 2007: 179) produced even more dismal findings - 86 percent European, with 4.6 percent Māori, 0.6 per cent Pasifika and 0.6 per cent Asian.

These statistics reflect how out of touch the mainstream journalism schools are with the demographic reality in the community. According to Census 2006, 'European' only make up 68 percent of the population. Yet while 72 percent of newsroom staff are European, according to the 2007 journalism industry 'diversity' survey (Journalism Training Organisation, 2007), the composition of journalism students at journalism schools is an overwhelming 85 percent 
European (Graph 4). Māori comprise 15 per cent of the population but only 13 per cent of the journalism student body (most of these at just two journalism schools - Waiariki and Waikato Institute of Technology). While the Asian community makes up almost 9 percent of the population, the number of Asian journalism students was less than 2 percent. This survey appeared at odds with a later informal survey of New Zealand's journalism schools by the JTO (Table 2), which showed 16 percent Māori (without Waiariki, 9.3 percent), 4.5 percent Pasifika and 2 percent Asian (including Indian). No other ethnicor religious, for example Muslim-minorities were indicated.

Noting how ethnic minority people were 'well under-represented' in New Zealand journalism, outgoing JTO executive director Jim Tucker (2007) highlighted the poor spread of a limited Asian intake at journalism schools in contrast to the Census: 'There are only three Asian and two Indian students among the 246 people currently enrolled in programmes at our 10 journalism schools. That compares with the population makeup of 10 per cent.' As indicated earlier in this article, the demographic projections are for even more dramatic changes in New Zealand by 2021 and 2026. According to the independent 2007 research report profiling New Zealand journalists in comparison with the 2006 Census (Hollings, 2007, p. 189):

\begin{abstract}
When it comes to diversity, the profession still does not reflect the rainbow of New Zealand's ethnic mix, though possibly more so than a decade ago. The overwhelming majority of journalists are still European, with Māori, Asians and Pasifika under-represented, particularly as reporters.
\end{abstract}

This view was shared by former newspaper editor and communication studies professor Judy McGregor, now Equal Opportunities Commissioner, when she addressed a Journalism Matters conference in Wellington in August 2007, organised to confront pressing issues facing the future of the media in New Zealand as an independent Fourth Estate. She said: 'The proportion of Māori, Pacific Island and Asian [journalists] in newsrooms is pitifully low and this has been a structural, systemic problem for decades (McGregor, 2007, p. 4).' But McGregor praised Fairfax Media for the composition of its first journalism intern scheme with five Māori, one Chinese and one Pacific Islander in the first intake of 17 from 230 applicants.

Since 2001, AUT University has supported and sponsored the Pacific 
Islands Media Association (PIMA) since its inception by hosting the annual PIMA conference on campus and also sponsoring two annual scholarships (both undergraduate and postgraduate) for Pasifika students at the university. A total of 13 students have gone through the AUT/PIMA scholarships and postgraduate students have completed research theses on the 2000 Fiji coup (Gounder, 2007), democracy and the media in Tonga and the challenges of a free media in Kiribati. At recent PIMA conferences there have been repeated calls for a 'Pacific journalism school' (Wanted: PI journalism school, 2005).

\title{
The AUT strategic response
}

In November 2005, a strategic development document prepared by this author for AUT University's School of Communication Studies (Robie, 2005. p. 6) recommended that a 'Pasifika media major' group be established to research and respond to initiatives by the Pacific Islands Media Association (PIMA) over a possible 'Pasifika journalism school' or Pasifika media programme. The AUT University Strategic Plan 2007-2011 targets Māori and Pasifika students and programmes for support. This includes a major push in the development of Māori and Pasifika media courses and in equity:

\begin{abstract}
AUT University will continue to be a university of opportunity. We will continue to support and encourage communities and groups who have been traditionally under-represented in higher education. This includes providing accessible and equitable pathways of learning from pre-degree to postgraduate levels, developing and maintaining targeted academic support programmes, and fostering social networks for students. We welcome diversity and encourage all staff and students to reach their potential, mindful of culture, socio-economic background, gender, disability, sexual orientation, ethnicity, age, or life experience.

During the last five years the University has identified three groupings as the priority for targeted support: Māori, Pasifika and people with a disability. These three groups remain the priority for 2007. (AUT Strategic Development Plan, 2007)
\end{abstract}

Already the university's demographics indicate that it has become the university of choice for New Zealand's ethnic minorities since it gained university status in 2000 as these communities' intakes have improved and the European/Pākehā proportion has gradually declined. By mid-2007, the number of European/Pakeha students had dropped to 44 percent compared 
to 51 percent in 2000 (AUT Institutional Resource Unit, 2007). This trend was also reflected in the School of Communication Studies. Currently three out of every 10 EFTS in the school is a diversity communications student and this is approaching the national census breakdown. Māori students peaked at 10 percent in 2002 but the phasing out of certificate courses led to a temporary drop to 8 percent two years later. Pasifika and Asian students have shown a steady increase.

A significant development in 2007 enhanced the school's commitment to diversity and equity objectives with the establishment of the Pacific Media Centre (PMC) as part of the newly created Creative Industries Research Institute (CIRI) with a commitment to Māori, Pasifika and ethnic media research. The Centre also provides media resources and publications, such as New Zealand's only journalism research journal, Pacific Journalism Review and three media books in the past six months.

\section{Conclusion}

While research about diversity and the media in New Zealand-particularly Pasifika and Asian-remains limited, it is clear that there is a growing need for both more diversity journalist representation in the mainstream media and better education in cross-cultural reporting and coverage of diversity issues. The demographic indicators underscore the urgency for both the mainstream media and journalism schools to be proactive about changes. Based on key points in this article and on JTO , PIMA and other diversity forum in the past five years, the following 10-point priority strategic plan has emerged:

1. Media employers and journalism schools must be committed to recruiting indigenous and ethnic minorities into the media and to make a clear and urgent signal for change.

2. Cross-cultural dialogue can only be achieved with diversity in the newsroom and all journalists being appropriately educated and trained (ie. te reo Māori language skills).

3. Everybody in the newsroom is responsible for reporting diversity, not just people with ethnic minority backgrounds.

4. Profiles should be developed about recruiting minorities to identify needs - such as bilingual, multilingual, good English skills and strong diversity community links. 
5. Industry role models should be used to identify and promote journalism as a positive and attractive career for minority communities.

6. More systematic use of identifying talent should be made in schools and in support of potential diversity journalists.

7. More workplace internships/exchanges should be provided for crosscultural reporting - such as providing opportunities for mainstream journalists to work in minority media environments, and vice versa.

8. Tailored diversity programmes need to be provided to ensure graduate journalists have recognition for cross-cultural reporting skills (ie. te reo and Pacific languages).

9. It is important to provide more diversity scholarships and incentives for diversity journalism. Models such as the Fairfax Media internship scheme and AUT's diversity and Pasifika scholarships are examples of good practice, and ought to be adopted elsewhere in the industry and journalism schools.

10. Journalism school intake criteria need to be modified to ensure diversity candidates have a fair and equitable chance of being selected. Many journalism schools use outdated criteria that are unfairly weighted against diversity prospects.

Finally, journalism schools can provide a lead. At present, they need to contest the media industry's globalised imperative and failure to keep pace with the demographic and cultural transformation. Journalism schools ought to revisit their selection criteria and use lateral thinking in finding more creative ways to boost their diversity intake. They should also target their in-house training publications to reflect better diversity reportage with a commitment to coverage that better represents diversity in the community in New Zealand, tangata whenua social development and the wider Pacific region. Their challenge now is to make the diversity mantra a reality.

\section{References}

10 human rights cases that made a difference. (2006). Wellington: NZ Human Rights Commission, Wellington. Retrieved on 5 July 2008, from www.hrc.co.nz/hrc_new/ $\mathrm{hrc} / \mathrm{cms} /$ files/documents/12-Dec-2006_12-35-21_DRT_Booklet_Final.pdf Archie, C. (2007). Pou kōrero: A journalists' guide to reporting Māori and current affairs. Wellington: NZ Journalists Training Organisation.

Asian people excluded from media, says TV producer, (2008, March 31). Pacific Media

Centre. Retrieved on 5 July 2008, from www.pmc.aut.ac.nz/globalwatch/080331_ AsianPeople.shtml 
AUT Institutional Research Unit, 2007, Demographic statistics summary.

AUT University Strategic Development Plan 2007-2011, 2007.

Bascand, G. (2008). Projections indicate increasing ethnic diversity. Retrieved on 3 July 2008, from www.stats.govt.nz

Belich, J., (1996). Making peoples: A history of the New Zealanders from Polynesian settlement to the end of the 19th century. Auckland: Penguin.

Brown, J. (2008, March 12). NiuFM denies bid for political influence. Pacific Media Watch. Retrieved on 5 July 2008, from www.pmc.aut.ac.nz/niusbeat/080312_ NiuFM.shtml

Coddington, D. (2006, November). Asian Angst: Is it time to send some back? North \& South, New Zealand.

Dean, B. (2006). Bohane's portrayal of spirit and war in Melanesia. Pacific Journalism Review, 12(2): 157-160.

Deuze, M. (2004). Global journalism education. In (Eds.) de Beer, Arnold, S., and John C. Merrill, Global journalism: Topical issues and media systems (pp. 128-141). Boston: Allyn and Bacon, Boston.

Dreaver, B. (2008, March 12). News boss's job questioned. Television New Zealand. Retrieved on 5 July 2008, from http://tvnz.co.nz/view/video_popup_windows_skin/1635405

Field, M., Baba, T., and Baba, U. (2005). Speight of violence: Inside the Fiji 2000 coup. Auckland: Reed.

Gounder, C. (2007). Reporting the Fiji coups: Fiji 2000-Journalists and the George Speight coup,' Pacific Journalism Review, 13(1): 125-141.

Helu Thaman, K. (2001). Reclaiming Pacific images: A view of communication and peace. Paper presented at an International Association for Mass Communication Research (IAMCR) conference, Budapest, September 6-10.

Hollings, J., Lealand, G., Samson, A., and Tilley, E. (2007). Profile 2007: The big NZ journalism survey: Underpaid, under-trained, under-resourced, unsure about the future - but still idealistic. Pacific Journalism Review, 14(2): 175-197.

Hollings, J. (2007). Still European and female, but older: Profiling the New Zealand journalist. Pacific Journalism Review, 13(1): 183-195.

James, C. (2006) From the Pacific: A New Zealand perspective on Australia's strategic role. Paper presented at the Australian Strategic Policy Institute's Global Forces Conference, September 26-27.

Lealand, G. (1988). Young, trained, female: A survey of New Zealand journalists. Australian Journalism Review, 10: 93-99.

Louw, P. E. (2008) Journalists reporting from foreign places,. In (Eds.) de Beer, Arnold, S. and John C. Merrill, Global journalism: Topical issues and media systems (pp. 151-162). Boston: Allyn and Bacon.

McGregor, J. (2007). The state of the news media in New Zealand? Keynote address presented at the Journalism Matters conference, Wellington, August 11-12.

Mason, A. (2007). Reporting the Fiji coups: Elite sources, journalistic practice and status quo. Pacific Journalism Review, 13(1): 107-123.

Mather, J. (2008). Māori Television strategy for success. Presentation to the WITBC 
2008 at Auckland, March 26.

Mediawatch (2006, July 6). Hubeditors. Radio New Zealand. Retrieved on 6 July 2008, from www.mediawatch.co.nz

Mediawatch (2001, July 8). Report: Pacific Island journalism. Radio New Zealand.

Retrieved on 22 November 2006, from www.mediawatch.co.nz/default,322.sm

MIT to offer first Māori media course taught in te reo. (2007, May 15). Pacific Media Centre Retrieved on 2 December 2007, from www.pmc.aut.ac.nz/niusbeat/070515_MIT.shtml

Morgan, A., Pifer, A., and Woods, K. (2006). The authentic voice: The best reporting on race and ethnicity. New York: Columbia University Press.

Nakhid, C. (2006). Ethics and the obstruction of social justice for Māori and Pasifika

(Pacific Islands) students in tertiary institutions in Aotearoa (New Zealand). Race, Ethnicity and Education, 9(3): 295-305.

NZ Journalists Training Organisation. (2007a). 'Reporting ethnic diversity 2007survey summary. Retrieved on 5 October 2007, from

www.journalismtraining.co.nz/diversity.html

NZ Journalists Training Organisation (2007b). Reporting diversity forum—workshop outcomes, May. Wellington: NZ Journalism Training Organisation.

NZ Journalists Training Organisation (2006). A national survey of New Zealand journalists 2006 - survey summary. Retrieved on 5 October 2007, from www. journalismtraining.co.nz/diversity.html

Oliver, P. (2007, June 11). Press council condemns ‘Asian angst' story. New Zealand Herald.

Radio NZ International wins global awards (2007, November 21). Pacific Media Centre, Auckland. Retrieved on 2 December 2007, from: www.pmc.aut.ac.nz/ niusbeat/071121_radionz.shtml

Rankine, J., Nairn, R., Moewaka Barnes, A., Gregory, M., Kaiwai, H., Borell, B., and McCreanor, T. (2007). Media and te tiriti o Waitangi 2007. Auckland: Kupu Taea.

Robie, D. (2007). Frontline reporting, ethos and perception: Media challenges in the South Pacific, Asia Pacific Viewpoint. 49(2): 213-227.

Robie, David, (2005a), South Pacific notions of the fourth estate: A collision of media models, culture and values. Media Asia, 32(2): 86-94.

Robie, D. (2005b). The road ahead: Diversity and publication strategy, 2006-2010. Auckland: School of Communication Studies, AUT University.

Robie, D. (2004). Mekim nius: South Pacific media, politics and education. Suva: University of the South Pacific Book Centre.

Rosenberg, B. (2008). NZ media 2007: The year of the accountant, Pacific Journalism Review. 14(1): 176-213.

Segedin, K. (2009, March 24). Bennett gives new Indian paper full marks. Pacific Media Centre News Blog. Retrieved on 20 April 2009, from http://pacificmediacentre.blogspot.com/2009/03/bennett-gives-new-indian-paper-full.html

Singham, M. (2006). Multiculturalism in New Zealand - the need for a new paradigm. Aotearoa Ethnic Network Journal, 1(1): 33-37. 
Statistics NZ. (2008). A changing New Zealand. Retrieved on 1 July 2008, from www.stats.govt.nz

Statistics NZ. (2006). New Zealand: Population/dwellings 2006. Retrieved on 5 October 2007, from

www3.stats.govt.nz/census_outputs/QuickStats_Snapshot_NZ.pdf

Statistics NZ (2004). Ethnic population projections: Issues and trends,' June, p. 9-14.

Retrieved on 5 October 2007, from www.stats.govt.nz/products-and-services/ Articles/pop-proj-Jun04.htm

Stuart, I. (2003). The construction of a national Māori identity by Māori media. Pacific Journalism Review 9: 45-58.

Stuart, I. (2002). Māori and the mainstream: Towards bicultural reporting, Pacific Journalism Review, 8: 42-58.

Stuart, I. (1996). Tauiwi and Māori media: The indigenous perspective. Pacific Journalism Review, 3:2: 102-111.

Taira, E. (2006). Māori media: A study of the Māori 'media sphere' in Aotearoa/New Zealand. Unpublished PhD thesis. Christchurch: Department of Politics and Mass Communication, University of Canterbury.

Tan, L. (2006). There's scope for more Asian involvement in the mainstream media: A discussion paper about journalism training needs for Kiwi Asian communities in New Zealand. Wellington: NZ Journalists Training Organisation.

Tucker, J. (2007). Ethnic diversity in journalism—numbers don't stack up. E-noted, n.d. Wellington: NZ Journalists Training Organisation. Retrieved on 29 November 2007, from www.journalismtraining.co.nz/diversity.html

Tucker, J. (2007). Reporting ethnic diversity, May 15, [slide presentation]. Wellington: NZ Journalists Training Organisation.

Tully, J. (2008) Reporting diversity. In (Ed.) Tully, J., Intro: A beginner's guide to professional news journalism (pp. 233-241). Wellington: NZ Journalists Training Organisation.

Tully, J. (2005). The media effect. In (Eds.) J. Henderson and G. Watson, Securing a peaceful Pacific (pp. 294-297). Christchurch: Canterbury University Press.

Utanga, J, (2007). Pasifika media in the digital era. Pacific Journalism Review, 3(1): 19-28.

Wairaiki programme and personnel changes. (2007). Journalism Education Association of New Zealand, retrieved on 2 December 2007, from www.jeanz.org.nz

Wilson, G., 2006, 'Breaking the circuit: A discussion paper about Maori and Pacific Island coverage in the New Zealand news media,' NZ Journalism Training Organisation (JTO), Wellington.

Wilson, G., 2005, 'Diversity and the Media,' Human Rights Commission, September 13, retrieved on 5 October 2007, from www.hrc.co.nz/hrc_new/hrc/ cms/files/documents/13-Sep-2005_15-35-12_Gary_Wilson_Diversity_and_the_ media.doc

Wanted: PI journalism school. (2005, October 21). Auckland: AUT: Te Waha Nui student journalism newspaper.

Whitireia journalism diploma goes mid year ... sort of. (2007, September 24). Whitireia 
Community Polytechnic. Retrieved on 17 December 2007, from www.whitireia. ac.nz/page_display.php?category_id=31\&subcategory_id=0\&page_id=400 Wong, S. (2006) Survey of ethnic minority publishers and broadcasters [Spreadsheet].

Dr David Robie is an associate professor in journalism and director of the Pacific Media Centre in the School of Communication Studies at New Zealand's AUT University. He has taught cross-cultural reporting as head of the journalism programmes at the University of Papua New Guinea (19931998) and the University of the South Pacific (1998-2002). He was awarded the 2005 PIMA Pacific Media Freedom Award for his contribution to the development of journalists in the Pacific and New Zealand. An earlier version of this article was presented as a paper under the title 'Diversity and the media in Aotearoa/New Zealand: The Pacific Media Centre initiative' at the Journalism Education Association of New Zealand conference at Massey University, 10-12 December 2007. The author would like to acknowledge the assistance on this paper by Del Abcede.

david.robie@aut.ac.nz

\title{
(3) Waiariki
}

Journalism Educators Association of New Zealand conference 'Walking the Talk'

Workshops and papers are invited from all those who teach, lecture and develop resources for the education of journalists in Aotearoa/New Zealand and around the world.

\author{
December 3-4, 2009 \\ in Rotorua and hosted by \\ Waiariki Institute of Technology \\ More details on www.jeanz.org.nz
}

